\title{
A NOTE ON \\ ESCAPE FROM ARBITRATION CLAUSES: \\ EFFECT OF THE NEW ARBITRATION ACT
}

\section{W.H. HURLBURT*}

\section{PURPOSE OF NOTE}

Escape from an arbitration into litigation has become more difficult. That is one effect of the new Arbitration Act. ${ }^{1}$ This note will compare the new Act with the previous Act ${ }^{2}$ in that respect and point out the significance of the changes.

A lawyer who drafts or approves a contract that includes an arbitration clause should note that such clauses are much more likely to be enforced than was the case in the past. They should address their mind to the likely effect of the clause and to the environment in which the clause is likely to operate. What kinds of disputes are likely to arise from the relationship between the contracting parties? Is arbitration the best way to resolve such disputes? Will the arbitration clause cover all of them? Will it lead to multiplicity of proceedings? Will the arbitration clause, in conjunction with the new Act, bring in all necessary parties and provide all necessary remedies? How can the clause be structured so as to ensure that arbitration will be the most suitable form of adjudication?

It is not the intention of this note to discourage the use of arbitration clauses. Its purpose is merely to emphasize that care is needed if the expected benefits of arbitration are to be obtained.

The recent decision in McCulloch v. Peat Marwick Thorne et al. ${ }^{3}$ and the Queen's Bench decision in Kaverit Steel and Crane Ltd. et al. v. Kone Corp. et al. ${ }^{4}$ might appear to run counter to the thesis of this note that an escape into litigation is more difficult. The note examines them below. The decision of the Court of Appeal in Kaverit, though it was decided under the International Commercial Arbitration Act, in my submission, settles the law along the lines suggested in this note.

\section{SUMMARY OF LAW UNDER THE OLD ARBITRATION ACT}

Under the old Act, the courts had a virtually untrammelled discretion to decide whether or not a party to an arbitration agreement could escape from that agreement into court. Sections 3 and 4 conferred the discretion. They read as follows:

3 If a party to a submission or a person claiming through or under him commences legal proceedings in a court against another party to the submission or a person claiming

Director Emeritus, Alberta Law Reform Institute and Counsel, Reynolds Mirth Richards \& Farmer. S.A. 1991, c. A-43.1 [hereinafter "the new Act"].

R.S.A. 1980, c. A-43 [hereinafter "the old Act"].

(1992) I Alta. L.R. (3d) 53 (Q.B.).

(1991), 119 A.R. 194 (Q.B.); (1992), 87 D.L.R. (4th) 129 (C.A.). 
through or under him in respect of a matter agreed to be referred, a party to the legal proceedings may at any time before delivering any pleadings or taking any other steps in the proceedings, apply to that court for an order staying the proceedings.

The court to which an application is made under section 3 may make the order on being satisfied

(a) that there is no sufficient reason why the matter should not be referred in accordance with the submission, and

(b) that the applicant was at the time when the proceedings were commenced and still remains ready and willing to do all things necessary to the proper conduct of the arbitration.

A recent example of a case in which, under the old Act, a court might refuse to stay a conflicting action is Fluor Canada Constructors Ltd. v. Lethbridge (City). ${ }^{5}$ In that case, a contractor applied for the appointment of an arbitrator under an arbitration clause in a construction contract. Madam Justice Conrad held, following Mobil Oil Canada Ltd. v. Pan West Engineering \& Construction Ltd, ${ }^{6}$ that the discretion to refuse to appoint an arbitrator, which would abort the arbitration, should be exercised on the same grounds as the discretion to refuse a stay of a conflicting action, which would also abort an arbitration. The decision is therefore an authority on the exercise of the discretion to grant a stay.

Madam Justice Conrad refused to appoint an arbitrator. She gave three reasons which will be paraphrased. First, allowing the contractor's claim against the owner and the owner's resulting claim over against the owner's engineer to be litigated in one action would avoid a multiplicity of proceedings ${ }^{7}$ and the associated risk that the arbitration would impose liability on the owner for the engineer's actions while different findings in the litigation would deprive the owner of its consequent claim over against the engineer. Second, there were difficult questions of law involved that could require numerous references to the court; the presence of legal questions does not necessarily preclude an arbitration, but legal complexity and its likely effect on an arbitration are facts to consider. Third, the case was not a fit and proper case for arbitration. This conclusion appears to follow from the points already mentioned. ${ }^{8}$

5. (1990), 98 A.R. 138 [hereinafter Lethbridge].

6. [1973] 1 W.W.R. 412 (Alta. T.D.S.C.).

7. Mustill and Boyd (M.J. Mustill \& S.C. Boyd Commercial Arbitration (Butterworths, 1982)) set out two additional kinds of situations in which multiplicity of proceedings will flow from arbitrating a dispute: (a) part of the relief claimed lies outside the powers of the arbitrator or does not fall within the scope of the agreement to arbitrate; and (b) proceedings between the same parties in relation to the same or related issues are already in progress in court or in another jurisdiction.

For a case falling on the other side of the line, see the later decision of Madam Justice Conrad in Top Notch Construction Lid. v. Western Irrigation District Board of Directors et al. (1991), 115 A.R. 290 [hereafter Top Notch]. A secondary lesson to be drawn from both Lethbridge and Top Notch is the importance of reviewing an arbitration clause in the context of the whole contract to be sure that it is clear when it applies and when it does not. 
Another recent and rather extreme example of the refusal of a stay is Dunwoody \& Company v. Thiessen. ${ }^{9}$ This was an action by an accounting firm to enforce a restrictive covenant in a partnership agreement. The defendant applied for a stay of the action because there was an arbitration clause. The chambers judge refused the stay. His principal reasons for refusing the stay were (a) that the plaintiffs in the action had asked for an injunction, the granting of which was beyond the powers of arbitrators; ${ }^{10}$ and (b) that the arbitration would require more time and result in more cost than the litigation. The Saskatchewan Court of Appeal declined to interfere with the exercise of his discretion.

Another ground on which the courts would refuse to grant a stay was that the defendant in the action (the applicant for the stay of the action) alleged that the plaintiff was guilty of fraud or conspiracy, or even professional negligence. The refusal was intended to give the plaintiff a chance to clear their name in open court." However, if the accused party wanted arbitration, a stay should be granted. ${ }^{12}$

Speaking in more general terms, the discretion to grant a stay was, according to Lord Macmillan, speaking in the House of Lords, ${ }^{13}$ to be exercised according to certain criteria. These were: (1) the precise nature of the dispute; (2) whether the dispute falls within the terms of the arbitration clause; (3) whether the arbitration clause is still effective; and (4) whether there is any sufficient reason why the matter in dispute should not be referred to arbitration.

In summary, the old Act, as interpreted by the courts, gave some weight to a contractual obligation to arbitrate, but it gave the courts a broad discretion to override the contract and allow a dispute to be litigated. This discretion constituted an escape hatch to which a party might resort if they had unwisely agreed to an arbitration clause or if they decided that litigation would give them a tactical advantage. As will be seen, the new Act is designed to narrow the escape hatch considerably.

\section{THE NEW ARBITRATION ACT}

The new Act reflects a distinct change in policy. It gives much more weight to the contractual right of a party to have a claim arbitrated, and it restricts the escape hatch to specific narrow cases. Reference may be made here to two reports which were accepted by the Legislature in enacting the new Act and which may be referred to in seeing what

(1989), 70 S.R. 189 (Sask. Q.B.); aff'd (1989), 74 S.R. 49 (Sask. C.A.) [hereinafter Dumwoody]. S. 31 of the new Act provides that an arbitral tribunal may order specific performance, injunctions and other equitable remedies.

See, for example. Charles Osenton \& Co. v. Johnston, [1942] A.C. 130 (H.L.).

Cunningham-Reid v. Buchanan-Jardine, [1988] 2 All E.R. 438 (C.A.), applying a statement by Lord Wilberforce in Camilla Cotton Oil Co. v. Granadex SA and Tracomin SA, [1976] 2 Lloyd's Rep. 10 (H.L.).

Heyman v. Darwin, [1942] A.C. 356, 370. The English authorities were usually applicable in view of the fact that the old Act was based on the Arbitration Act 1889 (U.K.), though it is always necessary to be sure that differences in later United Kingdom legislation did not make them inapplicable. 
deficiencies in the old law were to be rectified. ${ }^{14}$ They are the Alberta Law Reform Institute's Report 51, Proposals for a New Alberta Arbitration Act ${ }^{15}$ and the report presented to the Uniform Law Conference of Canada in 1989 by the Alberta Commissioners, which resulted in the adoption of the Uniform Arbitration Act. ${ }^{16}$

The Institute's report, in the commentary to its proposed section 8, which was the foundation of section $7(1)$ and section $7(2)^{17}$ of the new Act, said this:

Section 8 also recognizes the basic principle of entitlement to arbitration, and goes much further in giving effect to it. Under it, the court would be required to stay the action unless there is a fundamental defect in the foundation of the arbitration or undue delay in its prosecution.

\section{The Alberta Commissioners were even more explicit:}

... then, we do not really see why the complexity of the issues, the existence of questions of law, or allegations of fraud should have anything to do with what tribunal deals with a matter. There may be all sorts of reasons why a court would think that the parties were ill-advised to make a contract to arbitrate, but the fact remains that the parties have chosen arbitration and there is no reason to hack away at the agreement.

Section 7(1) and section 7(2) of the new Act are as follows:

7 (1) If a party to an arbitration agreement commences a proceeding in a court in respect of a matter in dispute to be submitted to arbitration under the agreement, the court shall, on the motion of another party to the arbitration agreement, stay the proceeding.

(2) The court may refuse to stay the proceeding in only the following cases:

(a) a party entered into the arbitration agreement while under a legal incapacity;

(b) the arbitration agreement is invalid;

(c) the subject-matter of the dispute is not capable of being the subject of arbitration under Alberta law;

(d) the motion to stay the proceeding was brought with undue delay;

See Mazurenko v. Mazurenko (1981), 30 A.R. 34, 42-3 (Alta. C.A.). It should be disclosed that the present author was a party to both reports.

15. Alberta Law Reform Institute. October 1988, at 74. It may be noted in passing that the judgment in the McCullough case quoted a passage from the Institute's Issues Paper No. 1, Towards a New Arhitration Act for Alberta, July 1987, and said that it caught the underlying philosophy of the new Act. The passage was actually a description of the law. Uniform Law Conference of Canada, Proceedings of the 71st Annual Meeting, August 1989, at page 141

17. There are differences between the Institute's section 8 and section 7 of the new Act, but the thrust is the same and the differences are not relevant to this discussion. 
(e) the matter in dispute is a proper one for default or summary judgment.

It will be seen that section 7(1) requires the court to stay "a proceeding in a court in respect of" a matter that is to be submitted to arbitration under an arbitration agreement. That is the general rule. Then section 7(2) lists some specific exceptional cases in which the court "may" refuse a stay, with the consequence ${ }^{18}$ that no arbitration may be commenced or continued. These exceptional grounds include three that go to the foundation of the arbitration. They are: the legal incapacity of a party to the arbitration agreement; the invalidity of the arbitration agreement; and the inarbitrability of the dispute under Alberta law. They also include grounds that show that a party has slept on its rights or is playing games. These are delays in bringing the application or the existence of grounds for a summary or default judgment. These are narrow grounds. The new Act does not give the court a general discretion to refuse a stay.

On the face of it, the new Act would require a court to stay an action in the circumstances of the Lethbridge case, the Dunwoody case, and the fraud or conspiracy cases referred to above. A possible multiplicity of proceedings; a lack of remedies; an allegation of fraud or other misconduct: none of these falls within the exceptional cases set out in section 7(2) of the new Act. To say that any of them does, would require an extraordinarily robust interpretation of the precise words of section $7(2)$. It is for the parties to decide whether disputes between them should be arbitrated or litigated and a court should not impose on them its ideas of convenience.

\section{THE MCCULLOCH AND KAVERIT DECISIONS}

Two recent Alberta decisions bear on the subject of staying conflicting actions. The first, McCulloch v. Peat Marwick Thorne et al, ${ }^{19}$ was an application under the new Act for a stay of a conflicting action. The Queen's Bench refused the stay. The action was brought by an accountant who claimed that a partnership agreement had been breached and that the defendants had committed other wrongs. The defendants applied for a stay on the basis of an arbitration clause covering "any dispute...relating to the construction, meaning or effect of anything in this agreement or the rights or liabilities of any party pursuant to this agreement...". In its first reasons for judgment, dated November 27, 1991, the Court considered section 7(2)(c) of the new Act. It first said this:

The question then is this: is the dispute capable of being the subject of arbitration under Alberta law?

The answer in this case is that the dispute falls outside of the arbitration clause found in the partnership agreement.

This is not, from a precedential point of view, alarming. If a dispute falls outside an arbitration clause, it is not covered by the new Act, and there is no reason why the court should stay an action brought to resolve the dispute. However, the Court went on to refer 
to, and apparently to apply, English authorities dealing with the exercise of the court's discretion under the old Act and concluded by saying that:

...it makes much more sense to have a dispute between the parties settled by one mechanism than to split the matter for example into breach of contract and accounting for arbitration and professional reputation and conspiracy for trial and in that case have the dispute run on parallel tracks, with duplication of costs, inconvenience and the possibility of inconsistent results.

There being no appeal from a decision under section 7 of the new Act, the stay application was reargued. The Court confirmed its decision, giving its reason as follows:

While the issues were revisited by excellent briefs, and while several new issues were raised and canvassed, again by excellent written briefs, I see no reason to change my view that the allegations in the statement of claim relating to conspiracy and defamation are not caught by the wording of the arbitration agreement and, therefore, pursuant to the new Arbitration Act, which I find applies, the subject matter of the dispute is not capable of being the subject of arbitration pursuant to Alberta law. ${ }^{20}$

It is clear from this passage that what the court held was (1) that the dispute was outside the arbitration clause, and (2) that the fact that the dispute was outside the arbitration clause meant that the dispute was not capable of being the subject of arbitration pursuant to Alberta law.

It is not clear why the Court found it necessary to resort to section $7(2)(c)$. Once is it held that a dispute is not within an arbitration clause, the situation can be characterized in either of two ways. One is that the Arbitration Act simply does not apply, because, under section 2(1), it applies only "to any arbitration conducted under an arbitration agreement or authorized or required under an enactment." The other is that section 7(1), which requires the Court to stay an action, does not apply, because the action is not "in respect of a matter in dispute to be submitted to arbitration under the agreement." If either the whole Act does not apply, or if the requirement of a stay does not apply, the Court can refuse the stay without resorting to section 7(2)(c).

But, be that as it may, the second reasons for judgment make it clear that the ratio decidendi for the refusal to grant the stay was that the dispute did not fall within the arbitration agreement. That being so, anything said in the first reasons for judgment suggesting that the subject-matter of a dispute "is not capable of being the subject of arbitration under Alberta law" merely because the Court thinks that it would be better to let the dispute be litigated is purely obiter dictum. It is also, in my submission, inconsistent with section 7 of the new Act.

The second case is Kaverit Steel and Crane Ltd. et al. v. Kone Corp. et al..$^{21}$ It arose under the International Commercial Arbitration Act ${ }^{22}$ and not under the new Arbitration Act. The counterpart ICAA provision does not talk about staying an action. What it does

\footnotetext{
20. Unreported Reasons for judgment, 2 April 1992, Edmonton Q.B., Action No. 910315426.

21. Supra, note 4.

22. R.S.A. 1980 , c. I-6.6 [hereinafter "the ICAA"].
} 
do is to require a court to "refer the parties to arbitration, unless it finds that the [arbitration] agreement is null and void, inoperative or incapable of being performed."23 If such an order is made and the arbitration proceeds, an action on the dispute would have to be stayed or struck out. In Kaverit, the Queen's Bench declined to stay an action that dealt with a dispute covered by an arbitration agreement. It held that the agreement to arbitrate had been rendered "inoperative or incapable of being performed" by the fact that other plaintiffs in the action "have raised legitimate causes of action which are connected to the main issue of breach of contract such that all matters should be tried in the same proceedings."

The Court of Appeal reversed this decision. Mr. Justice Kerans said:

It [the arbitration agreement] may not operate conveniently, but it cannot be said to be inoperative. The view taken by the leamed chambers judge adds a gloss to the word that it cannot, in all the circumstances, reasonably bear. ${ }^{24}$

And later:

That purpose [the achievement of orderliness and predictability essential to any international business transaction] would not be served by adopting an interpretation that puts the entire scheme at risk. The forum conveniens test almost always would defeat arbitration because, as Justice Stewart said in Scherk, it would invite "unseemly and mutually destructive jockeying."2s

As has been noted, the wording of section 7 of the new Act is different from the wording of Article II.3, but it serves a similar purpose. If a party to an arbitration agreement could, by injecting additional parties, additional causes of action or claims for additional relief into an action brought on a dispute that the parties had agreed should be arbitrated, the ingenuity of counsel could subvert almost any agreement to arbitrate. ${ }^{26}$ While the absence of a right of appeal under section 7 of the new Act prevents the granting or refusal of stays under it to reach the Court of Appeal, it seems that that approach of the Court of Appeal of Kavert should be followed in the Queen's Bench.

\section{JURISDICTION}

It was noted briefly above that there is no reason for the court to stay an action under section 7 of the new Act if there is no valid arbitration agreement or if the action does not cover a dispute that the parties have agreed to arbitrate. In such a case, the

The provision referred to in the judgments is Article II. 3 of the Comvention on the Recognition and Enforcement of Foreign Arbitral Awards, which is Schedulc 1 to the ICAA. Article 8(1) of the UNCITRAL Model Law on International Commercial Arbitration, which is Schedule 2 to the ICAA, is to the same effect.

24. Supra, note 4 at $138-139$.

25. Supra, note 4 at 139.

26. See also Boart Sweden $A B$ et al. v. NYA Strommes $A B$ et al. (1988), 41 B.L.R. 286 (Ont. H.C.) to the same effect. 
Arbitration Act does not apply at all and section 7 does not require the court to stay an action.

In the nature of things, such questions of boundary jurisdiction will ultimately be decided by a court. The question can come to the court in an action for a declaration or through the arbitration process.

Section 47 of the new Act deals with an action for a declaration. Under it, a party who has not participated in an arbitration proceeding can sue in the Queen's Bench for a declaration that the agreement to arbitrate is invalid or does not apply to the dispute that has allegedly been referred to arbitration. A court could, in my view, grant such a declaration even without section 47 , because if there is no valid agreement that a dispute will be decided by arbitration, a purported arbitration is not an arbitration within the meaning of the Arbitration Act and the Act simply does not apply. Even section 6, which regulates the use of the powers of a court, would not apply, because something that is not an arbitration is not a "matter governed by this Act."

Section 17 of the new Act deals with questions of jurisdiction that arise in the arbitration process. Section 17 applies if a party attacking an arbitral tribunal's jurisdiction has participated in the arbitrations. Under section 17(4) and section 17(6), a party who claims that a tribunal has no jurisdiction must make a timely objection to jurisdiction. Under section 17(1) the tribunal may rule on its own jurisdiction. If it does so as a preliminary question, a party who objects may apply to the Queen's Bench which may decide the question without further appeal. If the tribunal deals with the question of jurisdiction in its final award, a party may apply to the Queen's Bench to set aside the award on jurisdictional grounds under section 45(1). Section 17 is intended to strengthen the arbitration system and minimize game-playing and it is supported by later subsections of section 45 .

McCulloch v. Peat Marwick Thorne et al. ${ }^{27}$ may reflect a judicial tendency to interpret arbitration clauses narrowly so as to permit parties to escape into litigation. As noted above, the arbitration clause in that case covered any dispute relating to the rights or liabilities of any party pursuant to the arbitration agreement. According to the reasons for judgment, one of the claims in the conflicting action was breach of agreement. On the face of it, section 7(1) of the new Act required the court to stay the conflicting action because it was "a proceeding in a court in respect of a matter in dispute to be submitted to arbitration under the agreement." If that is so, section 7(5) applied. Under that subsection, the court "may stay the proceeding with respect to the matters in dispute dealt with in the arbitration agreement and allow the proceeding to continue with respect to other matters" if it finds two things. The first is that the agreement deals with only some of the matters in dispute in respect of which the proceeding was commenced. The second is that it is reasonable to separate the matters in dispute dealt with in the agreement from the other matters. This is an exception from section $7(1)$, which, as already noted, requires that the action be stayed. The effect of sections $7(1)$ and 7(5), in my submission, 
is that an action must be stayed if it covers a matter in dispute that is within the agreement to arbitrate, subject to the power of the court to stay it only in part if the other matters can reasonably be separated.

A case like Shell Canada Ltd. v. Vector Energy Inc. ${ }^{28}$ could still occur under the new Act. In that case, a party to an arbitration agreement, before an arbitral tribunal was appointed, sued for a declaration that a certain letter was not part of the arbitration agreement. The report of the case suggests that the amendment of the agreement by the letter was necessary to give the tribunal jurisdiction to decide the question submitted to arbitration. The judge held that the submitted question did not fall within the terms of the arbitration clause, broad though they were, and was therefore not arbitrable. Under section 47 of the new Act, the court would still have jurisdiction to make a declaration that the question submitted to arbitration did not fall within the arbitration agreement if, as was the case in Vector, the plaintiff had not participated in the arbitration.

However, the judge went on to hold that, even if the issue were within the scope of the submission to arbitration so that the arbitrators would have jurisdiction to consider it, he should decide the question anyway in order to save cost. The new Act would not permit the court to make a declaration on that basis over the objections of the defendant, as section $7(1)$ would require it to stay the declaration action.

The new Act, as has been seen, does not restrict a party's substantive right to escape from an arbitration on the grounds of lack of jurisdiction. It does, however, restrict a party's opportunities for game-playing, which is a different thing. Under it, a party must be alert to questions of jurisdiction and raise them in a timely manner or lose their escape hatch. The policy of the new Act with respect to legal objections to jurisdiction, to the tribunal, and to procedure, may be described in current colloquial terms as "use them or lose them."

\section{OTHER ARBITRATION REGIMES IN ALBERTA}

This discussion has dealt with the effect of the new Arbitration Act, which covers domestic arbitrations subject to Alberta law if its application is not excluded by statute or agreement. If the International Commercial Arbitration Act applies, the escape hatch afforded by the court's power to refuse to stay a conflicting action is even narrower. As mentioned earlier in this note, the court before which an action is brought must, "if a party so requests not later than when submitting his first statement on the substance of the dispute, refer the parties to arbitration unless it finds that the agreement is null and void, inoperative or incapable of being performed." This does not specifically call for the staying of a conflicting action, but that is implicit in it.

The court's power to refuse a reference to arbitration under the ICAA is thus limited to cases in which there are fatal defects in the underlying agreement to arbitrate the 
dispute. The Commercial Arbitration Act (Canada), ${ }^{29}$ which is also based on the UNCITRAL Model Law and which applies to all ordinary arbitrations under federal law, contains a similar limitation. The $I C A A$ also confers power on an arbitral tribunal to decide upon its own jurisdiction, subject to application to the court by a party who does not like the tribunal's decision on the question. The ICAA does not contain a counterpart of section $\mathbf{4 7}$ of the new Arbitration Act, which allows a party who has not participated in an arbitration to apply for a declaration that the arbitration is fatally flawed, but it may be said with some confidence the court would entertain such an application under its inherent jurisdiction over contracts.

\section{CONSIDERATIONS APPLICABLE TO ARBITRATION CLAUSES}

The advent of the new Arbitration Act is not a reason for deciding against an arbitration clause where arbitration would be advantageous to the parties. It is, however, a strong reason for paying considerable attention to an arbitration clause and to the environment in which the clause is likely to operate. It is not the function of this note to suggest what drafters should do, but some possible approaches might usefully be mentioned. One would be to define carefully the circumstances in which the clause is likely to apply, noting, however, that every exclusion from the purview of the clause will deprive the parties of the benefits of arbitration that they presumably want if they are contemplating an arbitration clause at all. Another approach, where there are interrelated contracts, as in the construction contract situation, might be to ensure that all the interrelated contracts contain an arbitration clause that will entitle a party to insist that all related disputes are arbitrated in a single consolidated arbitration in which all necessary remedies are available. ${ }^{30}$

\section{CONCLUSION}

Under the new Arbitration Act, parties who have made their beds by arbitration clauses must lie in them more often than the old Act compelled them to. It is, therefore, even more important nowadays for a lawyer who advises on an arbitration clause to be sure that the bed fits the client so that the client's extremities will not be chopped off, in true Procrustean manner, to make the client fit the bed. The benefits of arbitration may be great, but they should not be purchased at too high a cost in rights or remedies.

30. Mustill and Boyd, supra, note 7 at 110-16 discuss the problems of related and "string" claims, and a legal adviser who wants to provide for multiple arbitrations should consider what they have to say. 